\title{
INFECTIOUS BURSAL DISEASE IN QUAILS
}

(With 1 Table and 14 Figures)

By

AHLAM A. FARGHALY; M.M. SABRY

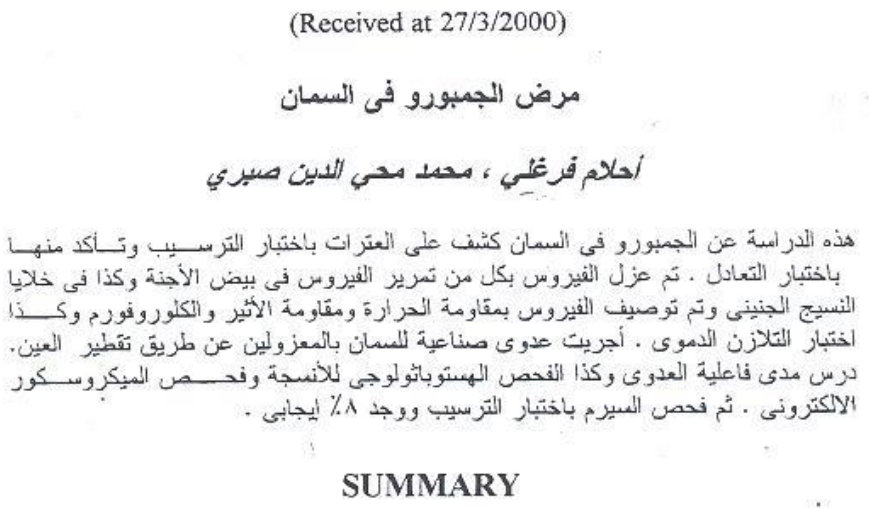

Infectious bursal disease (IBD) was detected in quail by agar gel precipitation test and confirmed by neutralization test. Virus isolation was carried out by inoculation in chicken embryo fibroblast and chicken embryo. Physical and chemical caharacter of the virus were tested the virus particles by electron microscopy the disease was reproduced in quail by intraocular inoculation using two isolates. Serum examination for infectious bursal disease revealed that $8 \%$ were positive for presence of antibodies against the disease.

\section{INTRODUCTION}

Infectious bursal disease (IBD) was firstly recorded by Cosgrove (1962) and was reported in many countries. 
Virus was recorded only in chicks until Allan et al, succeeded in (1973) in detection of infection with IBD in turkey.

Natural infection of ducks had been recorded by McNalty et al. (1979) and McFerran et al. (1980). Experimental infection of ducks with positive seroconversion was observed may be obtained (McFerran et al., 1980; Eddy, 1990; Okoye et al., 1990 and Khafagy et al., 1995)

Vind Vogel (1979) tried to infect 4 week old pigeon with infectious bursal disease virus (IBDV) from chickens and no microscopic changes in examined organ were observed. Viral antigen was not detected in bursa and sera was negative.

Louzis et al. (1979) recorded an outbreak of natural IBD in artificially reared pheasants with mortalities of $80 \%$. Natural infections of turkey and ducks were based on serologic evidence and isolation of IBDV form these species (Page et al., 1978; McNalty et al., 1979; Johnson et al., 1980; McFerran et al., 1980 and Perlman and Heller, 1981)

Hirose and Hirai (1976) found no antibodies against IBDV in egg yolk from quails, ducks, geese, bantame and pigeon. Nawath et al. (1978) detected no serologic evidence of IBDV infection in turkeys, guinea fowl and wild avian species.

Ezeifeka et al. (1992) and Maidygu et al. (1992) detected antibodies against $\mathrm{IBD}$ in sera of pigeon with agar gel precitipation test while Eziefeka recorded positive cases but Maidygu failed to detect antibody.

Hamouda et al. (1997) isolated four isolate from quail during his also made for viral isolation in migratory bird.

\section{MATERIAL and METHODS}

\section{1- Virus isolation}

This was done in 10 day-old embryonated chicken egg by chorioallantoic membrane inoculation as well as in chicken embryo fibroblast cell culture, using tissue homogenate as inocula; 3 blind passages were carried out.

2- Agar gel precipitating antibodies:

Precipitating antibodies against IBD were detected by immune diffusion test according to the method described by Anon (1974). 1.2\% agar dissolved in phosphate buffered saline (pbs) $8.5 \%$ Sodium chloride 
and adjusted to $7.2 \mathrm{ph}$. The medium was poured in petridishes. After solidification wells were cut. The known reference antisera were put in center ans serounded by antigen to be tested and the opposite were done with sera. The petri dishs were put in humid chamber at room temprature and periodically examined during 3 day for the presence of specific lines.

Sera: fourteen serum samples of quail were examined against reference antigen which was kindly provided by Dr. M.Sabry (Egytic) by agar gel precipitation test.

3- Thermostability test:

Isolates in the form of tissue cultures were subjected to 3 cycles of freezing and thawing and centrifuged, and distributed into tubes $(1 \mathrm{ml}$ per tube), incobated in water path at $56^{\circ} \mathrm{C}$ for $5,10,15,30,60,120$ minutes and samples were checked for infectivity by tissue culture inoculation.

4- Sensitivity to ether and chloroform:

Ether sensitivity was carried out according to the method described by Andrews and Horstman (1949)

Chloroform sensitivity technique was carried out according to the method described by Feldman and Wong (1961)

5- Haemagglutination activity (HA):

The isolates were tested for HA activity against chicken, duck, sheep, rat, mice, guinea pig, rabbit eryghrocytes according to Anon (1971).

6- Neutralization test:

Serial ten fold dilutions of antigen and constant amount of titrated reference serum $0.05 \mathrm{ml}$ of $\mathrm{CEF}$ added to each plate, the plates were incubated at $37^{\circ} \mathrm{C}$ in $\mathrm{Co}_{2}$ incubator for 3 days, was checked daily for neutralization indexes.

7 - Pathogenicity:

Two groups of quail were inoculated intraocularly by two isolates. Symptoms, PM lesions, histopathology and virus reisolation and pricipitating antibodies in sera at 7,18 days post infection.

Trial virus detection in spleen, bursa, liver, kidney at 7,18 days.

Trials for detection of virus by electron microscope.were done on bursa showing lesion at 18 days. Light microscopy:

Tissue speciemens from the bursa of Fabricious, spleen, kidney, and liver were fixed in $10 \%$ neutral buffer formalin, dehydrated in ascending grades of ethyl alcohol, cleared in methyl benzoate and embedded in 
paraffin. Tissue sections $5-7 \mu$ were stained with haematoxylin and eosin for light microscopical examination.

Electron microscopy:

Samples from the bursa of Fabricius and kidney were fixed in $5 \%$ cocodylate buffered glutaraldehyde, postfixed in $2 \%$ osmic acid and dehydrated and embedded in epon.

Semithin sections were obtained and stained with $0.25 \%$ toulidine blue The ultrathin sections were contrastained with uranyl acetate and lead citrate and examined with Jeol EM $100 \mathrm{CX}$ II at $60 \mathrm{KV}$.

\section{RESUTLS}

Serum: Five of fourty $(12.5 \%)$ of serum were positive for agar gel precipitation test.

Isolates: The present work 2 isolates were obtained from quails which showed dark bursa and petecial heamorhages in the outer surface of bursa (Fig. 1).

Bursa examined by agar gel precipitation test and inoculated in chicken CAM embryo showed odema of head, dwarfing, parboiled heart, liver changes. Blood bessels of legs were engorged with blood (Fig. 2)

Culture: 3 passages in chicken embryo Fibroblasts indicating cytopathic effect started from the first passage by rounding, clumbing cell, but nesting in the third passage only.

Heat resistance:

Virus was resistance to $56^{\circ} \mathrm{C}$ for 2 hours.

Effect of chloroform and ether: Virus was resistant to choloroform and ether. Table (1)

Table 1: Shows the titers of virus isolates before and after treated

\begin{tabular}{|c|c|c|c|}
\hline \multirow[t]{2}{*}{ Isolate } & \multirow[b]{2}{*}{ Before } & \multicolumn{2}{|c|}{ Titer of isolate } \\
\hline & & Ether & Choloroform \\
\hline $3 \mathrm{~B}$ & 4.75 & 4.75 & 4.75 \\
\hline 4 & 3.75 & 3.75 & 3.75 \\
\hline
\end{tabular}

\section{Haemagglutination:}

Isolates did not show haemagglutination activity against chicken, guinea pig, rat, mice duck, rabbit erythrocytes. 
Assiut Vet. Med. J Vol.43 No. 85, April 2000

Neutrilization index:

\begin{tabular}{c|c}
\hline Virus & Neutrilization index \\
\hline $3 \mathrm{~B}$ & 4.25 \\
4 & 1.75 \\
\hline
\end{tabular}

Experimental infection:

Two groups of quail inoculated with the two isolates showed ruffeled feather (Fig. 3). $25 \%$ of birds in group one at $7^{\text {th }}$ day showed haemorrhagic streaks in breast and thigh. In $12 \%$ of cases, dark bursa (Fig. 6) and kidney (Fig. 5) filled with urates in half of the cases. Whitish diarbea was observed $25 \%$ of cases at 8 days.

At 18 day, $25 \%$ of cases showed haemorrhages on the thigh (Fig 4). Bursas was dark in $50 \%$ of cases and reddened in the other, Liver was streaked with haemorrhages in all cases (Fig. 2) pricipitating lines in serum at $100 \%$ at 7 day and $33 \%$ at 18 days (Fig. 7)

Group 2: $12 \%$ of birds showed ruffeled feather at 7 days post inoculation, liver was streaked with hacmorhage, In $60 \%$ of cases, dark bursa in $70 \%$ and haemorhage in the knee. Precipitating linea in serum were $66 \%$ of cases at 7 days.

Virus detection in organ after infection.

\begin{tabular}{|l|c|c|c|c|}
\hline \multirow{2}{*}{ Organ } & \multicolumn{2}{|c|}{1 week } & \multicolumn{2}{c|}{$\mathbf{1 8}$ day } \\
\cline { 2 - 5 } & Gr. 2 & Gr. 7 & Gr 2 & Gr. 4 \\
\hline Spleen & - & $100 \%$ & $100 \%$ & $100 \%$. \\
\hline Kidney & $100 \%$ & $100 \%$ & $100 \%$ & $50 \%$ \\
\hline Liver & $100 \%$ & $100 \%$ & $100 \%$ & $33 \%$ \\
\hline Bursa & $100 \%$ & $100 \%$ & $100 \%$ & $50 \%$ \\
\hline
\end{tabular}

$\mathrm{Gl}=$ group 1

$\mathrm{G} 2$ - group 2

1 - Histopathology:

Histopathological examination of the bursa of Fabricious revealed necrosis and depletion of lymphocytes from the bursal follicles, interfollocular edema and heterophilic infiltration (Fig. 8). The bursa of normal quail showed no changes. Similar changes were observed in the white pulp of the spleen. There were necrosis and exhausion of lymphocytes from the periarteriolar lymphoid sheath with heterophilic infiltration (Fig. 9). The retecular cells around the sheathed arteries wree proliferated. The arteries showed vacuolation of tunica media and desquamation of the intimal cells (Fig. 10). The germinal centers 
(secondary white pulp follicles) were completely absent. The kidneys showed degenerative and necrotic changes in the epithelial cells of the proximal convoluted tubules, congestion of the interstitial blood bessels (Fig, 11). Interstitial lymphocytic infiltration and haemorrhage were also observed. The liver suffered diffuse fatty degeneration, congestion of the central veins and the vessels of the portal area (Fig. 12).

2- Electron microscopy:

Virus could not be detected at 18 days because it must be early before antidodies were obtained but the viral changes were recorded (Fig. $13,14)$.

Transmission electron micrograph of a reticular epithelial cell of the bursa ofFabricius showing clumping of the chromatin material along the nuclear membrane (Fig. 13).

The cytoplasm contained many phagolysosomes some of which contained like (Fig. 14). No virus particle could be detected (X 20,000).

\section{Discussion}

The present work deled with incidence of infectious bursal disease in quail. Quails were recorded as resistant for gumboro disease until. Hamouda (1977) isolated 4 isolates from quails. In this research, 2 isolates were isolated but further characterization steps and pathogenesis were done from quail. Affected bursae were dark bursa with petecial haemorages similar lesion recorded by Cosgrove (1962) Bond et at. (1979).

Commercial chicken embryos were inoculated via corrioallantoic membrane route $\mathrm{CAM}$, in order to obtain relatively higher titre as reported by Hitchner (1970).

Gumboro disease virus strain remained viable after 2 hours at $56^{\circ} \mathrm{C}$ as detected by C.P.E. in tissue culture. The isolate resisted treatment with chloroform and ether.

Chicken, ducks, mice, rat, rabbitte, guinea pig erythrocytes were not agglutinated with virus. The obtained properties of the-isolates were similar to those recorded for Cumboro disease virus by Benton et al. (1967); Cho and Edger (1968); Beteckand Mandelli (1969); Stevenson (1973); Bastami (1980) Mc NAlti (1982); Mousa et al. (1986) and Ahlam (1989). 
Birds wer infected intraocularly after Chevile (1967) and Badiola et al. (1969). The symptoms were ruffeld feathers, depression and similar symptoms were recorded in chicks by Cosgrorve (1962) and Ahlam (1998).

Haemorhages in skeletal muscles were widely reported by Snedekor et al. (1967); Lensin (1969); Lee (1979) and Mohamed (1983).

Heamorhages were more commanly observed in thigh and legs than in pectoral region similar to Delbono et al. (1969) and Mohamed (1983).

The bursal oedema and peticheal haemorhages on the wall of the bursa were reported by Chevile (1967); Zanati (1982) and Ahlam (1989).

Virus was detected from infected bird at 7 days $\mathrm{PI}$ and this agree with Ahlam (1989) and at 18 days which agree with Bayyari, et al. (1996).

Precipitating antibody in infected quails were detected at 8 and 18 days. Bastami (1980) recorded the appearance of precipitating antibodies from 4 days which increased at 10 days and decreased at 18 days.

Congestion of the renal paryenchema was more prominant in chicken which agree with Hitchner (1963); Delbono et al. (1969); Boushra (1982) and moultiple focal aggregations were mainly mononuclear cells and in the interstitial tissue of renal tissue. Similar results were recorded by Bushra (1982) and Ley et al. (1983)

Spleen showed necrosis and exhaustion of lymphocyte from periarteriolar lymphoid sheath with heterophilic infilteration on the artery. The germinal centers were completely absent. This agree with the periateriolar lymphoid sheath with heterophilic infilteration. Similar findings were reported by Halmoldt and Garner (1964); Cheville (1967), Lensing (1969); Mohamed (1983), but Pattison et al. (1975) cited the lymphoid necrosis only.

Bursa of Fabricious revealed necrosis and depletion of lymphocytes from the bursal follicles, interfollicular oedema and heterophilic infilteration and similar findings were also reported by Chiville (1967); Riggenbach (1968); Lee et al. (1987) and Peiakoveki et al. (1980). Virus was not be detected by electron microscope at 18 days because this time is late but only cellular changes because virus cannot be detected when the bird form antibody. 
Assiut Vet. Med. J. Vol.43 No. 85, April 2000

\section{REFERENCES}

Ahlam, A. Farghily (1989): Infectious bursal disease in chicken and turkey. Ph.D. Vet. Med., Assiut Univ.

Ahlam, A.A.; Agag, Asia El-Sawy, I.M. Sokkar (1968): Evidence of IBDV infection in turkey and chickens. Beni Suef Vet. Med. Res., Vol. VIII, No, 2.

Andros and C.H. Horsiman, D.M. (1949): The suseptibility of virus to ethy ether, Microbiology, 3: 290-297.

Anon (1977): Methods for examination poultry bilogica and for identificat in and quantifing Avian pathogen, National Academy of Science Washington DC.

Bakalin, V.A.; Kudnyavstev, F.S. Radchuk, L.A.A. (1982): Pathology of avian infectious bursitis, Veterinariya, Moscouss R No, $3: 37$ 39.

Barnas, H.J.; Wheeler, J.; Reed, D. (1982): Serologic enidence of infectious bursal disease virus infection in lowa turkeys Avian Diseases 26: 56-565.

Bastami, M.A. (1980): Studies on Gumboro disease in poultry and its relation to vaccination against some poultry disease. Thesis Ph.D. Department of Vet. Medicine, Cairo Univ.

Boushra, H. (1982): Pathogenesis of renal lesion in some avian disease M.V.Sc., Dept. of Path., Vet. Med., Cairo Univ.

Bayyari, G.R.; Story, J.D.; Boasl, J.N. and Skeeles, J.K. (1996): Pathogenicity studies of an Arkansas varian infections bursal disease virus. Avian Disease, 40: 518-532.

Bond, D.s.; Edgar, S.A.; Caldevin, G.G. and Ramas, D.N. (1979): Infectious bursal disease in Puerto Rico broilers. Avian Dis., 14 404-405.

Cheville, N.F. (1967): Studies on the bursa of fabricius, spleen and thymus of chicken. Am. J. Path., 51: 529-551.

(Cho, Y. and Edgar, S.A. (1968): Characterization of infectious bursal agent. Poultry Sci, 48: 2102-2109

Cho, Y. and Edgar, S.A. (1972): Characterization of infectious bursal disease. Poultry Sci., 51: 60-69.

Cosgrove, A.S. (1962): An apparently new disease of ebicleins ovian necrosis. Avian Diseases, 6: 285-289. 
Delboni, G., Agrimi, P. and Braea, G. (1969): Gumboro Disease. Annali Fac. Med. Vet. Pisa, 21: 41-45.

Edgar, S. and Cho, Y. (1965): Avian nephrosis (Gamboro disease) and its control by immunization. Poultry Sci., 44: 43-66

Eddy, R.K. (I990): Antibody response to infectious bursal disease virus serotype 1 and 2 in ducks. Vet. Record, 127:128.

Ezeifeka, G.O.; Dowoh, S.K.; and Moh, H.U. (1992): Involvement of wild and domestic birds in the epidemiology of newcastle disease and infectious bursal desease in Zara, Nigeria. Bulletin of Health and Production in Africa, 40 (2): 125-127.

Fadly and Nazeria, K. (1983): Pathogenesis of infectious bursal disease in chickens infected with the virus at various ages. Avian Diseases, 27 (3): 714-723

Giam Brone, JJZg Fletsher, O..J.; Lukert, P.D.; Pages, R.K.; Edsoncae (1978): Experimental infection of turkey with infections bursal disease virus, Avian Dis., 22; 454-458.

Hirose, M. and Hirai, K. (I976): Precipitating antibody against infectious bursal disease virus in egg yolk and serum of chickens. Research Bull. of the Fac. of Agriculture, Gifu Univ., 39: 165-176

Hitchner, S.B. (1970): Persistance fo parentral of infectious bursal disease antibody and its effects on suseptibility of young chickens. Avian Dis, 15:894-900.

Hamouda, M.S.M.; Abeldaim, M.M.; Naltie, E.K.; Eltrabili, M.A.M. Enany, M.E. and Afaf Amin (1997): The role of migratory birds in the transmission of some viral diseases. Bini Suef Vet. Med. Res., Vol. 16, No. 2

Helmboldt, C.F. and Garner, E. (1964): Experimentally induced gumboro disease (IBD). Avian Dis., 8: 561-575.

Khaphagy, A.K.: A. Soltan, Assia, M. Elsawy, A.A. El-Gohary and Magda (1995): Pathogenecity of very virulant infectious bursal disease virus to ducks and pigeons. J. Egypt. Vet. Med. Assoc. 55 No. 6: 1473-1488.

Johnson, d.C.; Lukert, P.O. and Page, R.K. (1980): Field studies with convalescent serum and infectious bursal disease vaccine to control turkeycoryra. Avian Dis., 24: 386-392.

Lee, D.H. (1979): The pathogenesis of infectious bursal disease in specific pathogen free chickens. Diseration abstracts international. B. (43): 40 (3142). 
Lensing, H.H. (1969): Gumboro disease. Neth. J. Vet. Sci., 2: 117-124. Ley, D.H.; Stor, N.; Bicklord, A.A.; Yamamoto, R. (1979): An infectious bursal disease virus outbreak in 14-15 week old chickens. Avian Diseases, 23 (1): 235-240.

Maudgue, Tawari, S.G. and Nawathe, R.R. (1992): Studies on the prevelance of infectious bursal disease in local indogenous chickens and pigeon in Maiduguri, Borno state (Nigeria). Indian Journal of Virology, $8(1): 18-21$.

McFerran et al., J.B.; McNalty, M.S.; McRillop, E.A.; Cannav, T.J.; McKraken, R.M.; Collin, Disi and Allon, G.M. (1980): Isolation and serological studies with infectious bursal disease virus from fowl, turkey and ducks. Demonstration of second serotype. Avian Pathology, 9: 395-404.

McNalty, M.S.; Allan, M. and McFerran, J.B. (1979): Isolation of infectious bursal disease virus from turkeys. Avian Pathol., 8: 205-212.

Mohamed, A.T. (1983): A study on the pathogenesis of Gumboro disease in experimentally infected chick. Thesis of Ph.D., Pathology, Dept Vet. Med., Cairo Univ.

Mousa, S.; Bayoumi, A. and Soliman, A. (1986): Infectious bursal disease (Gumboro). Orpc. $70^{\text {th }}$ Ann. Mut. Us, Live stock sonit. Ass., (1966), PP 438-439.

Omunkwo, O. (1975): An out break of infectious bursal disease (IBD) of chickens in Niguia Vet. Record, 97 (22): 433

O Koye, J.O.: iquomw, E.P. Nwoschn, C. (1990): Pathogenicity of infectious bursal disease, in local Nigerian ducks. Trap. Anim., Health prod., 22, 3: 160-162.

Page, R.K.; Flotcher, G.J.; Kukert, P.D. and Rimmlo, R. (1978): Rhinotracheitis in turkey poults. Avian Dis., 22: 529-534.

Perelmen, B. and Hellen, R.D. (1981): Perlimary serological survay for infectious disease in turkey in Isnoil. Refuah, Vet, 38: 12-16.

Snedekor, C.; Wills, F.K. and Maulthrays, I.M. (1967): Some studies of infectious bursal agent. Avian Dis., (11): 519-528.

Vinel Vogel, H. (1979): Ressitance of pigeon to Gumboro (Avian bursal) disease virus. Annalasda, Medi. Vet. 123 (4): 285-286. 


\section{Assiut Vet. Med.J.Vol. 43 N. 85, April 2000}

\section{LEGENDS OF FIGURES}

Fig. 1: Bursa of natural infection.

Fig. 2: Liver streaked with haemorrhages.

Fig. 3: Quail showed ruffled feather.

Fig. 4: Haemorrhage in thigh.

Fig. 5: Agar gel precepitation test from serum.

Fig. 6: Purple bursa in infected quail.

Fig. 7: Agar gel precepitation test from infected organ.

Fig. 8: Bursa showing necrosis and depletion of lymphocytes.

(H.\&E. 40x).

Fig. 9: Spleen showing exhustion of lymphocytes from periarteriolar lymphocytes sheath with heterophilic infiltration (H.\&E. 40 x).

Fig. 10: The arteries showing vacuolation of tunica media and desquamation of intimal cells (H.\&E. $65 \mathrm{x}$ ).

Fig. 11: Kidney showing congestion of interstitial blood vessels. (H.\&E. $10 \mathrm{x}$ ).

Fig. 12: Fatty change and congestion in central vein (H.\&E. 10).

Fig. 13: Clumping of chromatin material.

Fig. 14: The cytoplasm contain phagolysosome. 


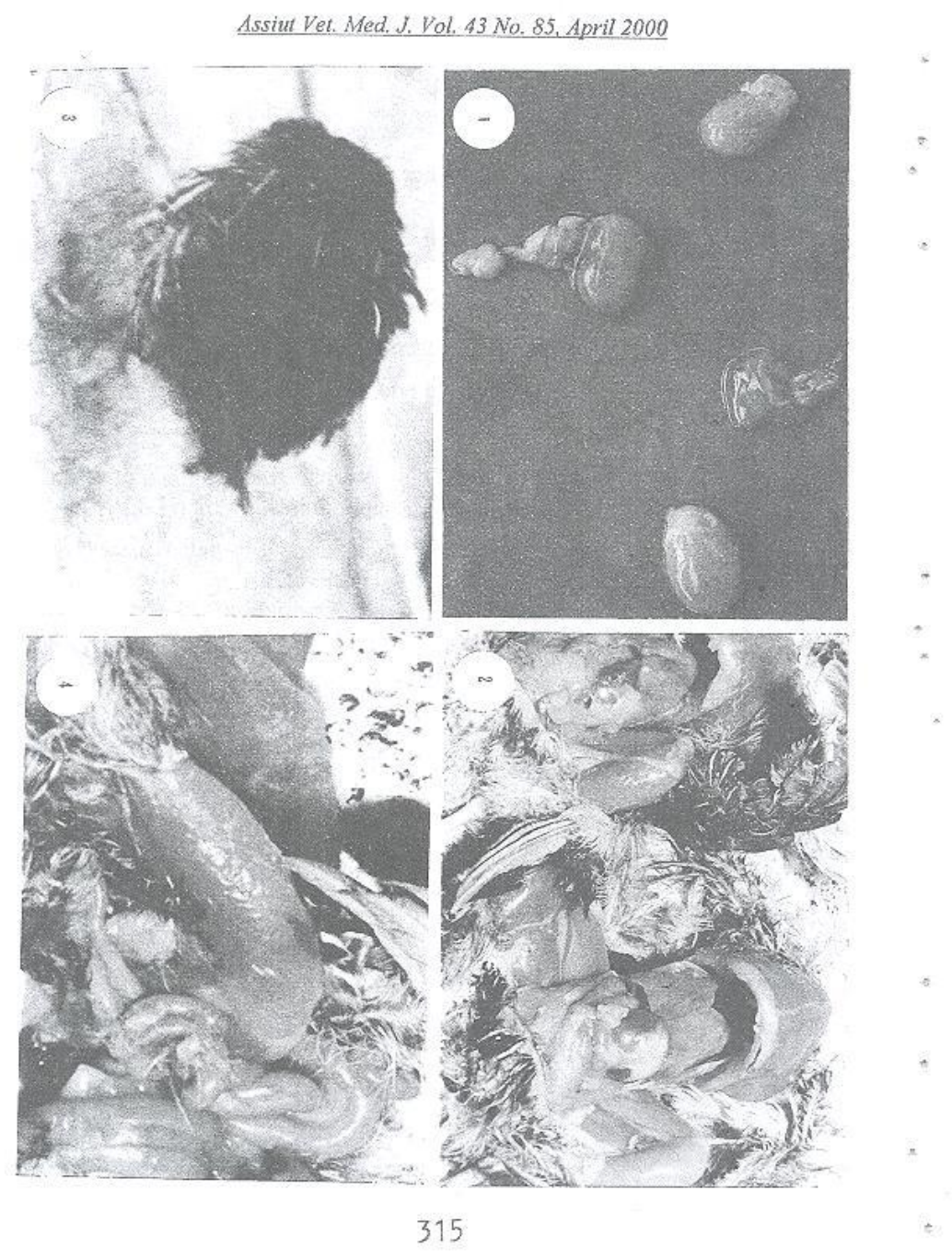


Assiut Vet. Med. J. Vol. 43 No. 85, April 2000
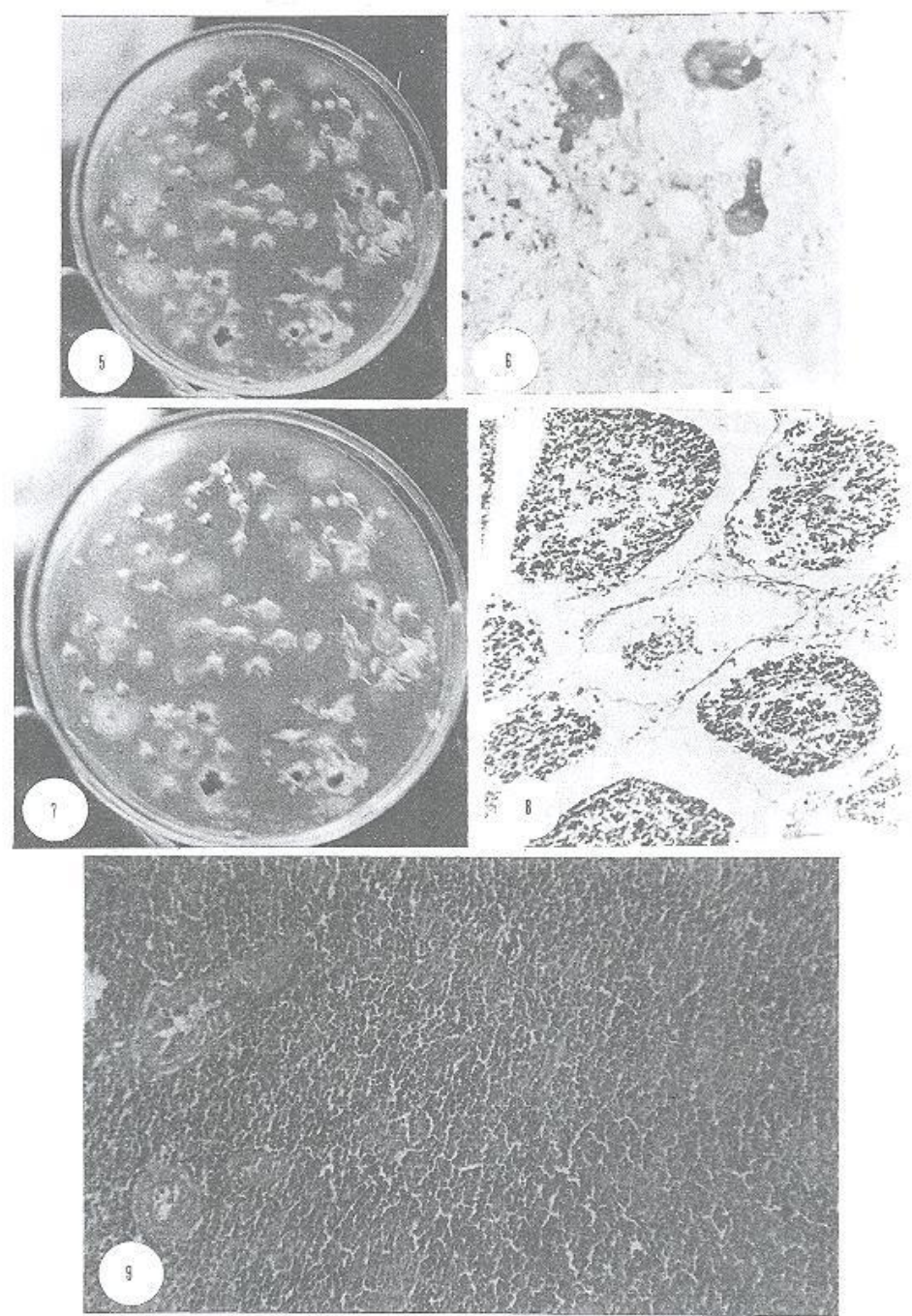
4.ssius Vet. Med 1. Vol. 43 No. 85, April 2000

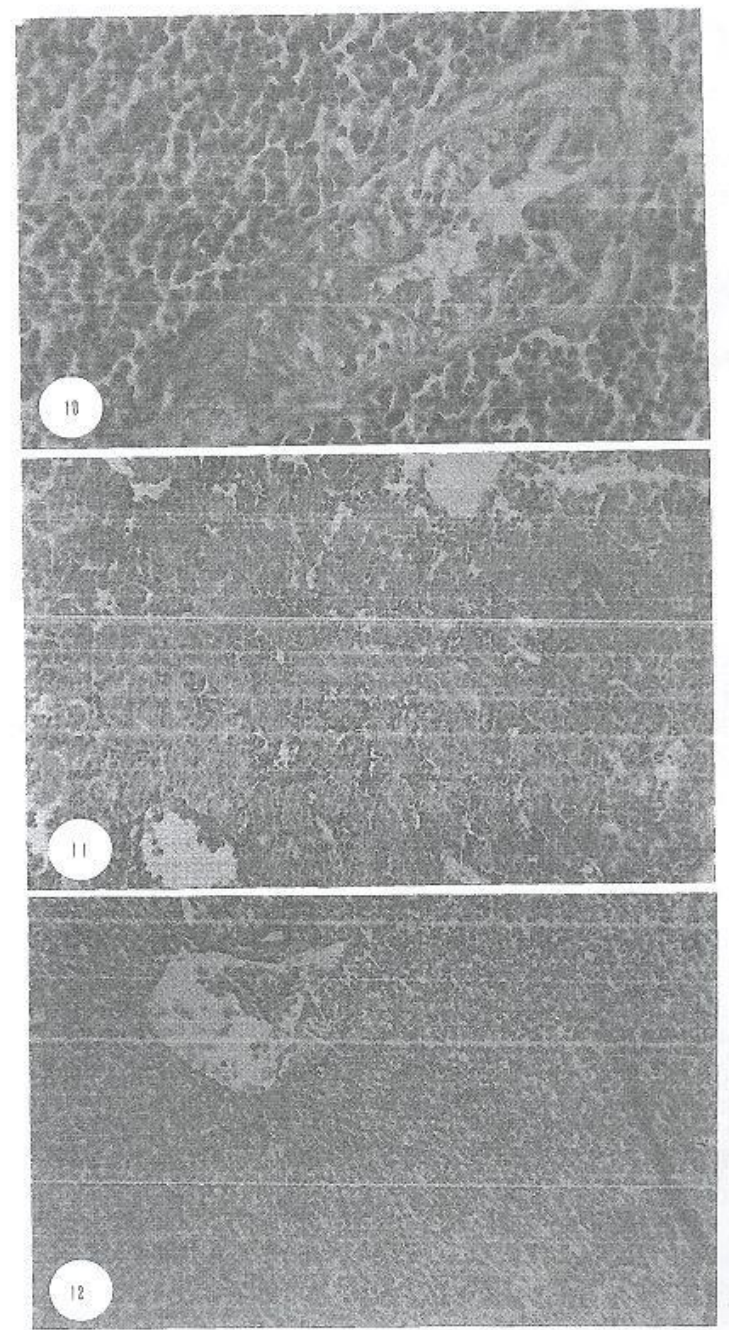

317 
Assiut Vet. Med. J. Vol. 43 No. 85, April 2000

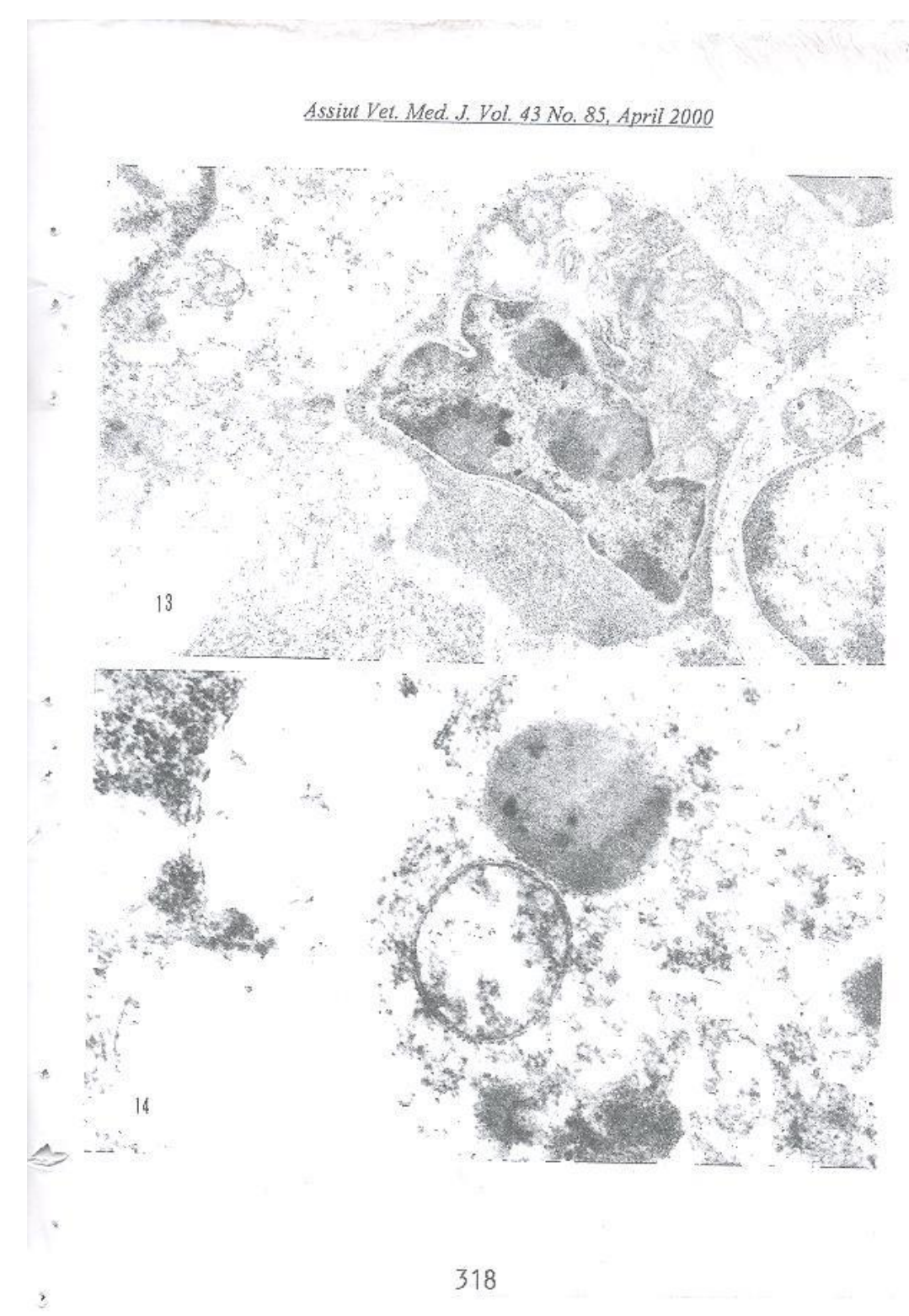

